\title{
La mediación penal y su prohibición en supuestos de violencia de género: modelo español
}

\author{
Criminal mediation and its prohibition in cases of \\ gender violence: the Spanish model
}

\section{Laura Álvarez Suárez ${ }^{1}$}

Universidad de Oviedo - España

alvarezlaura.uo@uniovi.es

http://orcid.org/0000-0001-7710-0913

\begin{abstract}
RESUMEN: Este trabajo pretende analizar la conveniencia o no de mantener la prohibición de mediación en delitos de violencia de género que establece el ordenamiento jurídico español. En España todavía no se han regulado procedimientos de justicia restaurativa en el ámbito penal, pero esto no ha sido impedimento para que el legislador excluyera la mediación en todos los supuestos de violencia de género, pese a las grandes críticas de la doctrina. Éstas han cobrado más fuerza que nunca tras el mandato europeo de instaurar mecanismos de justicia restaurativa penal, pues se considera que la nueva regulación debería ir acompañada de la derogación expresa de dicha prohibición. El estereotipo de víctima de violencia de género que establece la ley vigente permite aventurar que lo más adecuado sería abolir la prohibición y permitir que estas víctimas puedan someterse a un procedimiento mediador si es su voluntad y concurren una serie de presupuestos.

Palabras-clave: violencia de género; mediación; víctima; resolución; conflicto.
\end{abstract}

ABSTRACT: This work aims to analyze whether it is convenient to maintain the prohibition of mediation in gender violence crimes established in the Spanish legal system. In Spain, restorative justice procedures have not yet been regulated within the criminal sphere, but this has not been an impediment for the legislator

1 Doctoranda en Derecho y Colaboradora de Honor del área de Derecho Procesal de la Universidad de Oviedo. 
to exclude mediation in all cases of gender violence, despite the abundant criticisms from the doctrine. These have become stronger than ever after the European mandate to establish mechanisms of restorative justice; it is sustained that the new regulation should be accompanied by the express derogation of said prohibition. The stereotype of gender violence victim established by the current law allows us to argue that it would be more appropriate to abolish the prohibition and allow these victims to submit to a mediation procedure if it is their will and a series of prerequisites are also present.

KEYWORDS: gender violence; mediation; victim; resolution; conflict.

SUMARIO: Introducción. 1. Marco legal de la prohibición de mediación en supuestos de violencia de género. 2. Críticas e incoherencias de la prohibición legal. 3. Desventajas y ventajas de la mediación en el ámbito penal, y en especial, en los supuestos de violencia de género. 3.1. Argumentos a favor. 3.2. Argumentos en contra. 4. Propuestas lege ferenda para una futura reforma. Valoración final. Bibliografía.

\section{INTRODUCCIÓN}

El trabajo tiene por objeto de estudio la posibilidad de instaurar en España la mediación en el ámbito penal, y en concreto, en el de la violencia de género. Existen normas europeas que obligan a los Estados de la Unión a implantar mecanismos de justicia restaurativa en todos los delitos en que lo consideren conveniente. España prevé la justicia restaurativa en el orden penal, pero no ha llevado a cabo su desarrollo legal. Sin embargo, la ausencia de una regulación de procedimientos de justicia restaurativa penal no ha impedido que el legislador prohíba la mediación en los delitos de violencia de género.

Esta prohibición ha suscitado un gran debate doctrinal, entre los que estiman que la interdicción de la mediación en este tipo de delitos es adecuada debido a la ausencia de equidad entre la víctima (mujer) y el agresor (hombre) y, los que entienden que se trata de un error colosal debido a que en materia de violencia de género no existe homogeneidad ni en los supuestos ni en el tipo de víctimas, a lo que hay que añadir que la 
desigualdad entre partes y el miedo de las víctimas no son insuperables ${ }^{2}$. Esta prohibición legal, y los impedimentos que establece la normativa de protección de las víctimas de violencia de género para que se puedan desarrollar procedimientos de mediación en estos casos, no han sido obstáculo para que la doctrina haga propuestas lege ferenda en aras a instaurar este mecanismo en supuestos de violencia de género ${ }^{3}$.

2 En contra de la aplicación de la mediación en los supuestos de violencia se pueden señalar, entre otros autores a DEL POZO PÉREZ, M., "Matices y acotaciones sobre la prohibición de mediación del art. 44.5 de la Ley Orgánica 1/2004", La Ley, No 98/99, p. 1-11, 2012, FUENTES SORIANO, O., "Sobre la mediación penal y su prohibición en violencia de género". En: CASTILLO FELIPE, R. y TOMÁS TOMÁS, S. Estudios sobre la mediación y arbitraje desde una perspectiva procesal, Thomson Reuters Aranzadi, p. 239-277, 2017. Como posiciones a favor se pueden apuntar, entre otras, CASTILLEJO MANZANARES, R., "Hipótesis de partida acerca de la posibilidad de mediación en supuestos de violencia de género", Diario La Ley, No 8882, p.1-9, 2016 y LARRAURI PIOJAN, E., “Justicia restauradora y violencia doméstica”. En ASUA BATARRITA, A. y GARRO CARRERA, E., Hechos postdelictivos y sistema de individualización de la pena, p.125-144, 2009. Texto disponible en: http:// www.susepe.rs.gov.br/upload/1325076458_Justicia\%20Restauradora\%20 y\%20Violencia\%20Dom\%C3\%A9stica-\%20Elena\%20Larrauri.pdf (último acceso febrero 2019).

3 Entre otros autores han hecho propuestas lege ferenda MARTÍNEZ GARCÍA, E., "Mediación penal en los procesos por violencia de género. Entre la solución real del conflicto y el ius poniendi del Estado", Revista de Derecho Penal, $\mathrm{N}^{\circ}$ 33, p. 20 y ss., 2011, CANO SOLE, Ma A., "La mediación penal como método de resolución de conflictos. Posibilidades de aplicación a los delitos de violencia de género y doméstica”, La Ley Penal, N 109, p. 11 y ss., 2014, CASTILLEJO MANZANARES, R., "Hipótesis de partida acerca de la posibilidad...", trab. cit., p. 8, SALVADOR CONCEPCIÓN, R., "Beneficios y perjuicios del uso de la mediación en el ámbito penal. Especial alusión al supuesto de violencia de género", La Ley Penal, No 112, p. 4, 2015, GUARDIOLA LAGO, $\mathrm{M}^{\mathrm{a}}$. J., "La víctima de violencia de género en el sistema de justicia y la prohibición de la mediación penal”, Revista General de Derecho Penal, N ${ }^{\circ}$ 12, p. 33 y ss., 2009 y ARANGÜENA FANEGO, C., "Sistemas alternativos de resolución de conflictos en el ámbito penal”. En: ARANGÜENA FANEGO, C, HOYOS SANCHO, M. y CABRERA MERCADO, R., Análisis de medidas para mejorar la protección judicial y policial de las víctimas de violencia de género, Ministerio de Sanidad, Política Social e Igualdad, Madrid, p. 157-160, 2011. Texto disponible en: https://www.mimp.gob.pe/files/programas_nacionales/pncvfs/Proyecto_Apoyo_Asociacion_Juristas/Analisis_Medidas_Mejorar_Proteccion_Policial_Judicial_Victimas_Violencia_Genero.pdf (último acceso febrero 2019). 
El problema principal radica en que para el legislador español es ineludible elaborar una serie de normas que den cumplimiento al mandato europeo referente a la justicia restaurativa penal. Sin embargo, antes de llevar a cabo esta tarea de desarrollo legal debería plantearse si verdaderamente es conveniente o no mantener la prohibición de la mediación en los delitos de violencia de género. Este trabajo pretende dar una respuesta coherente y satisfactoria a esta cuestión tras el análisis de la normativa legal, de las desventajas y ventajas que supondría establecer la mediación en estos casos, así como de las propuestas lege ferenda que plantean los defensores de la abolición de dicha prohibición.

\section{Marco legal de La prohibición de mediación en supuestos DE VIOLENCIA DE GÉNERO.}

En España ya se había prohibido la mediación en los delitos de violencia de género, incluso antes de que existiese una Ley que regulase el procedimiento de mediación ${ }^{4}$. La Ley Orgánica 1/2004, de 28 de diciembre, de Medidas de Protección Integral contra la Violencia de Género (en adelante, LOVG), prohibió la mediación en su ámbito de aplicación, en su art. 44.5 que introdujo un nuevo art. 87 ter en la Ley Orgánica 6/1985, de 1 de julio, del Poder Judicial (en lo sucesivo, LOPJ), para atribuir competencias en el orden penal y civil a los Juzgados de Violencia contra la Mujer que la propia Ley crea, concluyendo en su apartado quinto que “en todos estos casos está vedada la mediación". Varios años después, se aprobó la Ley 5/2012, de 6 de julio, de mediación en asuntos civiles y mercantiles (en adelante, LM), que excluye expresamente la mediación en el orden penal de adultos [art. 2.2, apartado a)].

Se ha considerado que la prohibición del art. 87 ter. LOPJ tuvo su razón de ser en la necesidad de transmitir a la sociedad que la violencia de género no era un asunto privado, que las partes podían solucionar

4 LARRAURI PIOJAN ha puesto de manifiesto que la prohibición de la mediación en supuestos de violencia de género es una medida prematura que impide analizar en qué casos podría ser beneficiosa, más si se tiene en cuenta que todavía se están estudiando las ventajas e inconvenientes de la mediación (LARRURI PIOJAN, E., “Justicia restauradora y violencia...”, trab. cit., p. 18.). 
satisfactoriamente dialogando de puertas para dentro del hogar. Así se pone de manifiesto en la propia Exposición de Motivos de la LOVG, que declara que "la violencia de género no es un problema que afecte al ámbito privado". Sin embargo, en ese momento todavía se estaba iniciando el cambio de percepción legal de las acciones delictivas basadas en el género tras casi quince años de la promulgación de la LOVG, se puede decir que la percepción de la sociedad en materia de violencia de género ha cambiado y podría ser un buen momento para plantearse la posibilidad de la mediación penal en ciertos supuestos de violencia contra las mujeres si concurren determinadas condiciones ${ }^{5}$.

La crítica más compartida en la doctrina sobre LOVG es que infantiliza a la mujer presumiéndola falta de autonomía e incapaz para tomar decisiones sobre su propia vida, debido a su supuesta invalidez para defenderse. El estereotipo de víctima de violencia de género que adopta el legislador español es monolítico y en muchas ocasiones no coincide con la realidad, pretende proteger a las víctimas de forma paternalista y sectorial, sin tener en cuenta su voluntad, pero quizás sería más conveniente protegerlas teniendo en cuenta su libertad de decisión y no a costa de la misma ${ }^{6}$.

En este sentido, se ha puesto de manifiesto que la prohibición categórica de la mediación para todos los delitos conceptuados como violencia de género en la LOVG, sin hacer excepciones en cuanto al tipo de delitos, de víctimas o del momento del proceso penal, impide distinguir los supuestos en los que no se puede utilizar la justicia restaurativa

5 BORGES BLÁZQUEZ R, "La prohibición de mediación penal en violencia de género ¿éxito o fracaso?, Diario La Ley, N 9100, p. 4, 2017.

6 En la doctrina española hay autores que señalan expresamente que la LOVG infantiza a la mujer víctima de violencia de género, el término "infantilizar" significa según la RAE “conferir a algo o a alguien cualidades infantiles”. SERRAMIÀ BALAGUER, L, "Nuevas oportunidades para la justicia restaurativa en el sistema penal tras las reformas legales del año 2015: Especial incidencia en la violencia de género", Dereito, Vol. 26, N² 2, p. 10, 2017 y ORTIZ PRADILLO, J.C., "Estereotipos legales en la lucha contra la violencia machista: la irrelevancia de la voluntad de la víctima”, Diario La Ley, N $^{\circ} 8697$, p. 5, 2016. En este sentido, ORTIZ PRADILLO considera que dicha Ley no tiene en cuenta la voluntad de la víctima y que contribuye a reforzar el estereotipo sexista de la vulnerabilidad de la mujer (ORTIZ PRADILLO, J.C., "Estereotipos legales en la...", trab. cit, p. 2). 
por la situación de desequilibrio que existe entre las partes, de aquellos otros, identificados y tutelados por los profesionales que se encargarían de llevar a cabo la mediación, en los que bien desde un inicio, bien en un momento posterior, se comprueba la equivalencia de posiciones y la voluntad informada de participar en un proceso de esta naturaleza. Reprimiendo de este modo la LOVG, la principal finalidad de la mediación penal, que no es otra que conferir un mayor protagonismo a la víctima en el proceso ${ }^{7}$.

De acuerdo con la exclusión del art 2.2 de la LM, la mediación penal de adultos aún no está regulada ni en la Ley de Enjuiciamiento Criminal ni en ninguna otra Ley penal ${ }^{8}$, pero la instauración de la justicia restaurativa en el orden penal parece inminente en España tras la promulgación de la Ley 4/2015, de 27 de abril, del Estatuto de la víctima del delito (en adelante, EVD) que, en su art. 15 dispone que "las víctimas podrán acceder a los servicios de justicia restaurativa” el precepto plantea la necesidad de integrar este tipo de mecanismos como instrumentos para lograr la reparación material y moral de la víctima, pero no determina si debe tratarse propiamente de mediación o de cualquier otro mecanismo9.

El EVD se aprobó con la finalidad de trasponer la Directiva 2012/29/UE del Parlamento Europeo y del Consejo, de 25 de octubre de 2012, por la que se establecen normas mínimas sobre los derechos, el

7 RODRÍGUEZ YAGÜE, C., "Prohibición de la mediación en los delitos de violencia de género: su incidencia en la ejecución”, La Ley Penal, № 130, p. 5, 2018, LARRAURI PIOJAN, E., “Justicia restauradora y violencia...”, trab. cit., p. 18.

8 Sin embargo, existen preceptos del Código Penal español (CP) que confieren consecuencias jurídicas al acuerdo de mediación en el procedimiento penal: En la fase de instrucción el acuerdo de reparación obtenido en un proceso de mediación puede implicar la aplicación de la atenuante del art. $21.5^{\circ} \mathrm{CP}$, en la fase posterior a la sentencia y previa a la ejecución puede servir para otorgar la suspensión o sustitución de la pena privativa de libertad (art. 88 CP) y, en la fase de ejecución la mediación penal puede ser valorada para que el penado obtenga el tercer grado penitenciario, la libertad condicional o para que solicite el indulto. Véase VIDALES RODRÍGUEZ, C., "La mediación penal análisis y perspectivas tras la reforma del Código Penal y la aprobación del Estatuto de la víctima del delito", Revista Aranzadi de Derecho y Proceso Penal, N³9, Cizur Menor, p. 1-19, 2015.

9 FUENTES SORIANO, O., "Sobre la mediación penal y su prohibición...", trab. cit., p. 262. 
apoyo y la protección de las víctimas de delitos (en adelante, Directiva 2012) y por la que se sustituye la Decisión marco 2001/220/JAI del Consejo. Dicha Directiva en su considerando 46 dispone que los servicios de justicia reparadora como la mediación "pueden ser de gran ayuda para la víctima, pero requieren garantías para evitar toda victimización secundaria y reiterada, la intimidación y las represalias". El citado considerando también manifiesta que el objetivo principal de estos servicios debe ser "satisfacer los intereses y las necesidades de la víctima, reparar el perjuicio que se le haya ocasionado e impedir cualquier otro perjuicio adicional"10.

La doctrina siempre ha estado muy dividida respecto a la prohibición de la mediación en el ámbito de la violencia de género, entre los que consideran que la misma es adecuada en estos supuestos debido a la falta de igualdad de las partes, y los que entienden que es un craso error si se tiene en cuenta la gran diversidad de supuestos y tipos de víctimas que existen en materia de violencia de género ${ }^{11}$. El debate ha cogido más fuerza que nunca tras la promulgación del EVD y la ineludible implantación de la justicia restaurativa en el orden penal. Sin embargo, el art. 15 EVD recoge implícitamente la prohibición de la mediación en violencia de género al establecer como uno de los requisitos para poder acceder a los servicios de justicia restaurativa que "no esté prohibida para el delito cometido".

10 El art. 12 de la Directiva 2012 se establecen las condiciones mínimas para que la víctima pueda acudir a los servicios de justicia restaurativa: “a) que se recurra a los servicios de justicia reparadora si redundan en interés de la víctima, atendiendo a consideraciones de seguridad, y se basan en el consentimiento libre e informado de la víctima; el cual podrá retirarse en cualquier momento; b) antes de que acepte participar en cualquier proceso de justicia reparadora, se ofrecerá a la víctima información exhaustiva e imparcial sobre el mismo y sus posibles resultados, así como de los procedimientos para supervisar la aplicación del acuerdo; c) el infractor tendrá que haber reconocido los elementos fácticos del caso; d) todo acuerdo deberá ser alcanzado de forma voluntaria y podrá ser tenido en cuenta en cualquier otro proceso penal; e) los debates en los procesos de justicia reparadora que no se desarrollen en público serán confidenciales y no se difundirán posteriormente, salvo con el acuerdo de las partes o si así lo exige el Derecho nacional por razones de interés público".

11 Véase la nota a pie de página número 2 referente a las posiciones de la doctrina a favor y en contra de la prohibición de la mediación en supuestos de violencia de género prevista en el artículo 87 ter LOPJ. 
La postura de la LOVG ha sido acogida por las Naciones Unidas y por la normativa internacional, en tal sentido, el Manual de legislación de la ONU sobre la violencia contra la mujer (publicado en el año 2010) recomienda prohibir explícitamente la mediación en todos los casos de violencia contra la mujer ${ }^{12}$. Por su parte, el Convenio $N^{0} 210$ del Consejo de Europa sobre prevención y lucha contra la violencia contra las mujeres y la violencia doméstica, más conocido como el Convenio de Estambul debido a la ciudad en la que se aprobó en el año 2011, y que fue firmado por la Unión Europea y por todos los estados miembros, establece que las partes adoptarán las medidas legislativas o de otro tipo necesarias para prohibir los modos alternativos obligatorios de resolución de conflictos, incluidas la mediación y la conciliación, en lo que respecta a todas las formas de violencia incluidas en el ámbito de aplicación del convenio (art. 48.1) ${ }^{13}$.

En tal sentido, ARANGÜENA FANEGO ha llamado la atención en que la prohibición del Convenio de Estambul, de acuerdo con lo establecido en su Informe Explicativo, únicamente se refiere a aquellos supuestos en los que las leyes pudieran imponer el carácter obligatorio de acudir a la mediación, pues con esta imposición se quebraría uno de los principios

12 Texto disponible en: http://www.un.org/womenwatch/daw/vaw/handbook/Handbook-for-legislation-on- VAW-(Spanish).pdf (último acceso febrero 2019).

${ }_{13}$ El art. 3 del Convenio de Estambul, establece el concepto de los distintos tipos de violencia. Define la "violencia contra las mujeres" como una violación de los derechos humanos, y una forma de discriminación contra las mujeres, que designa todos los actos de violencia basados en el género que implican o pueden implicar para las mujeres daños o sufrimientos de naturaleza física, sexual, psicológica o económica, incluidas las amenazas de realizar dichos actos, la coacción o la privación arbitraria de la libertad en la vida pública. Por "violencia doméstica" entiende todos los actos de violencia física, sexual, psicológica o económica que se producen en la familia o en el hogar entre cónyuges o parejas de hecho antiguos o actuales, independientemente de que el autor del delito comparta o haya compartido el mismo domicilio que la víctima. El "género" lo define como todos los papeles, comportamientos, actividades y atribuciones socialmente construidos que una sociedad concreta considera propios de hombres y mujeres"; y la "violencia contra las mujeres por razones de género" como toda violencia contra una mujer porque es una mujer o que afecte a las mujeres de forma desproporcionada. 
que deben inspirar la mediación, esto es, la voluntariedad ${ }^{14}$. Más lejos ha ido el Pacto de Estado contra la violencia género, aprobado por el Pleno del Congreso el 28 de septiembre de 2017, para hacer efectivo el Convenio de Estambul en el ordenamiento español, pues entre sus medidas se contempla la de "reforzar en la legislación y en los protocolos que se aprueben y revisen, la absoluta prohibición de la mediación en los casos de violencia de género" (número 116).

\section{CRíticas e inCOHerencias de LA PROHibición legal.}

En primer lugar, es necesario apuntar que en realidad no existe una prohibición genérica a la mediación en violencia de género en España, el 87 ter. 5 LOPJ, sólo prohíbe la mediación en la criminalidad derivada de la concepción de violencia de género que la propia LOVG define. Pero el concepto de violencia de género que establece la LOVG es muy restringido ${ }^{15}$, limita la misma a la violencia ejercida sobre las mujeres por "sus cónyuges o de quienes estén o hayan estado ligados a ellas por relaciones similares de afectividad, aun sin convivencia”, pero la violencia de género es mucho más extensa y comprende supuestos de violencia familiar, de agresión sexual, acoso laboral, ablación genital, penalización de la infidelidad femenina, etc. ${ }^{16}$ En tal sentido, CASTILLEJO MANZA-

14 ARANGÜENA FANEGO, C., "Sistemas alternativos de resolución de conflictos...", trab. cit., p. 142.

15 El art. 1.1 LOVG define la violencia de género como la "manifestación de la discriminación, la situación de desigualdad y las relaciones de poder de los hombres sobre las mujeres, se ejerce sobre éstas por parte de quienes sean o hayan sido sus cónyuges o de quienes estén o hayan estado ligados a ellas por relaciones similares de afectividad, aun sin convivencia". Englobando dicha violencia "todo acto de violencia física y psicológica, incluidas las agresiones a la libertad sexual, las amenazas, las coacciones la privación arbitraria de la libertad".

DEL POZO PÉREZ, M., "Matices y acotaciones sobre la prohibición...", trab. cit, p. 2, SERRAMIÀ BALAGUER, L., "Nuevas oportunidades para la justicia restaurativa en el sistema...”, trab. cit., p. 5 y SÁNCHEZ RUÍZ, I. C., y GARCÍA-LONGORIA SERRANO, $\mathrm{M}^{\mathrm{a}} \mathrm{P}$., "Un sistema alternativo para la gestión de conflictos en casos de violencia de género: La mediación", Revista chilena de Derecho y Ciencia política, Vol. 6, № 3, p. 70, 2015. Respecto al carácter restringido del concepto de violencia de género en la legislación española 
NARES considera, con acierto, que no existe ninguna razón para que el legislador prohíba la mediación penal con parejas o ex parejas, y no la prohíba respecto de las madres e hijas víctimas de violencia doméstica, o en los casos que exceden del plano familiar ${ }^{17}$.

En segundo lugar, la prohibición legal afecta exclusivamente al procedimiento de mediación, pero no a otros procedimientos de justicia restaurativa como los familiy group conference ${ }^{18} \mathrm{u}$ otros procedimientos en los que intervienen, aparte de la víctima y el autor del delito, familiares o miembros de la comunidad. La doctrina considera que esto tiene su razón de ser en el desarrollo que ha experimentado la mediación penal en la Europa continental, como instrumento más habitual de justicia restaurativa. Sin embargo, no puede perderse de vista que la prohibición legal establecida permite la utilización de otros procedimientos restaurativos distintos de la mediación en supuestos de violencia de género, sin que éste hubiera sido, ni mucho menos, el propósito del legislador ${ }^{19}$.

Además, es necesario destacar que la mediación podría utilizarse una vez finalizada la fase de instrucción, debido a la ubicación del art. 87 ter. donde se establecen las competencias de los Juzgados de Violencia

véase ÁLVAREZ SUÁREZ, L., "La posición jurídico-procesal de las víctimas de violencia de género: estudio hispano-italiano”, Revista de derecho y proceso penal, $\mathrm{N}^{\circ} 51$, p. 149 y ss., 2018, y GIL VALLEJO, B. “A vueltas con el artículo 416 LECrim. (Repercusión de la Sentencia del Tribunal Supremo de 14 de julio de 2015 en el uso de la dispensa del art. 416.1 LECrim., por las víctimas de la violencia de género. La mediación en el ámbito de la violencia de género. Necesidad de flexibilización del sistema actual”, Diario La Ley, N8764, p. 2-4, 2016.

17 CASTILLEJO MANZANARES, R., "Hipótesis de partida acerca de la posibilidad...", trab. cit., p. 9.

18 Esta metodología nació en Nueva Zelanda y se está extendiendo por todo el mundo, consiste en una reunión formal mediada entre miembros de la familia extensa, entendida ésta como miembros de la familia nuclear, otros parientes más lejanos, amigos, vecinos, etc.; y otros funcionarios, tales como trabajadores sociales o la policía, con respecto al cuidado y la protección o la ofensa criminal a un niño o a un adolescente. La mediación de los profesionales va dirigida al empoderamiento de la familia y ofrece recursos para que la voz del niño sea siempre escuchada.

19 SERRAMIÀ BALAGUER, L., "Nuevas oportunidades para la justicia restaurativa en el sistema...”, trab.cit., p. 19 y GUARDIOLA LAGO, Ma. J., "La víctima de violencia de género en el sistema de justicia...”, trab. cit., p. 20 
sobre la Mujer. El mismo se encuentra dentro del Capítulo V de la LOPJ bajo la rúbrica "De los Juzgados de Primera Instancia e Instrucción, de lo Mercantil, de lo Penal, de Violencia sobre la Mujer, de lo Contencioso-Administrativo, de lo Social, de Vigilancia Penitenciaria y de Menores". Disponiendo el art. 87 ter, apartado uno, que los Jugados de Violencia sobre la Mujer conocerán de la "instrucción" de determinados delitos ${ }^{20}$.

De otro lado, el ámbito de aplicación de la exclusión del art. 87 ter LOPJ no es una cuestión pacífica. Parte de la doctrina entiende que se refiere tanto al ámbito penal como al civil, ya que el precepto a la vez que proscribe la mediación establece la competencia de los Juzgados de Violencia sobre la Mujer, que pueden conocer de asuntos penales y civiles, a lo que se añade, que el literal del art. 44.5 LOVG prohíbe la mediación "en todos estos casos"21. Postura que se vería reforzada con la sentencia de la Audiencia Provincial de Barcelona, de 12 de enero de 2007, la misma tenía por objeto cuestiones civiles relativas a un divorcio, el Tribunal estimó que no era posible continuar el procedimiento de terapia conjunta que había sido recomendado por los especialistas, ni tampoco comenzar el procedimiento de mediación familiar que avalaba la psicóloga, porque el art. 44.5 LOVG prohíbe expresamente el uso de la mediación en casos de violencia de género.

Otro sector doctrinal, en cambio, considera que no se puede prohibir la mediación en un ámbito en el que no existen normas que la regulen, por lo que el art. 87 ter. 5 LOPJ no podría ir más allá de prohibir la mediación civil en supuestos de violencia de género ${ }^{22}$. No obstante, se ha reconocido que, aunque la prohibición del art. 87.ter 5 LOPJ aparentemente está circunscrita al ámbito del Derecho de familia, no parece susceptible de separarse artificiosamente del ámbito penal de la violencia de género ${ }^{23}$.

20 GUARDIOLA LAGO, Ma . J., "La víctima de violencia de género en el sistema de justicia... “, trab. cit, p. 31-32 y SERRAMIÀ BALAGUER, L., "Nuevas oportunidades para la justicia restaurativa en el sistema...", trab.cit., p. 20.

21 DEL POZO PÉREZ, M., "Matices y acotaciones sobre la prohibición...”, trab. cit, p. 3 y 5.

22 BORGES BLÁZQUEZ, R., "La prohibición de mediación penal en violencia...”, trab cit., p. 2.

23 FUSTERO BERNAD, A., "La mediación en los delitos de violencia de género", Revista Internacional de Mediación, № 1, p. 15, 2014. 
Ahora bien, si es cierto que la mediación civil, en todo caso, está prohibida en supuestos de violencia de género, resulta paradójico que se permita que en los Juzgados de Violencia sobre la Mujer se celebren divorcios y separaciones de mutuo acuerdo en los que ambas partes presentan un convenio regulador, de acuerdo con el art. 770.9 de la Ley de Enjuiciamiento Civil, que dispone que "las partes de común acuerdo podrán solicitar la suspensión del proceso de conformidad con el art. 19.4 de esta Ley para someterse a mediación”. Se ha considerado, apropiadamente, que, en los procesos matrimoniales conexos a la violencia de género la celebración de este tipo de acuerdos quebranta la prohibición del art. 87 ter $5 \mathrm{LOPJ}^{24}$.

Asimismo, si la prohibición del art. 87 ter 5 LOPJ se extiende al ámbito penal, no debería poder aplicarse la figura de la conformidad en los supuestos de violencia de género ${ }^{25}$, pues, aunque no se basa en la disponibilidad de las partes sobre el objeto del proceso, puede implicar la negociación entre la acusación y la defensa y provocar un efecto inmediato en la causa, impedir la celebración del juicio oral y que se dicte sentencia inmediatamente. Sin embargo, la conformidad puede ser utilizada sin restricción en los delitos de violencia de género y, además, no existe limitación alguna para las conformidades "beneficiadas" de los juicios rápidos, dónde el acusado puede conseguir un beneficio de un tercio de reducción de la pretensión punitiva con la que se ha conformado ${ }^{26}$.

Por último, resulta llamativo que el legislador no haya prohibido la mediación en supuestos de violencia de género cuando el agresor es un menor, ya que en el único ámbito penal en el que se contempla la mediación es en la jurisdicción de menores. La Ley Orgánica 5/2000, de 12 de enero, reguladora de la Responsabilidad Penal de los Menores (en lo sucesivo, LORPM), establece en sus artículos 19 y 27.3 la posibilidad de acordar el sobreseimiento del expediente por conciliación o reparación, conduciendo ambas derivaciones por el procedimiento de mediación entre la víctima y el menor. No obstante, hay autores que consideran que la

24 MOLINA CABALLERO, $\mathrm{M}^{\mathrm{a}} \mathrm{J}$., "Algunas fronteras de la Ley Integral contra la violencia de género: Jurisdicción de menores y mediación”, Revista Criminológica de Ciencia Penal y Criminología, No 17-24, p. 17, 2015.

25 El arts. 787 y 801 LECrim.

26 MOLINA CABALLERO, $\mathrm{M}^{\mathrm{a}}$ J.., "Algunas fronteras de la Ley Integral contra la violencia de género...”, trab. cit., p. 15 y 23. 
prohibición del art. 87 ter 5 LOPJ no afecta a la Jurisdicción de Menores porque la LORM no contiene ninguna previsión especial en materia de violencia sobre la mujer y, además, la LOPJ solo afecta a las competencias de los Juzgados de Violencia sobre la Mujer ${ }^{27}$.

\section{Desventajas y Ventajas de la mediación en El Ámbito penal, Y EN ESPECIAL, EN LOS SUPUESTOS DE VIOLENCIA DE GÉNERO.}

La discusión acerca de la idoneidad de implantar la mediación en el ámbito penal y de la conveniencia de la prohibición de someter a este procedimiento los delitos de violencia de género establecida en el 87 ter 5 LOPJ, ha llevado a la doctrina a esgrimir poderosos argumentos tanto a favor como en contra de la utilización de este tipo de mecanismos de justicia restaurativa en el orden penal, y en concreto, en la violencia de género.

\subsection{Argumentos en CONTRA.}

El primer argumento de la doctrina para rechazar la instauración de la mediación en el ámbito penal es la trasgresión del principio de legalidad. La mediación como cualquier otro mecanismo de solución negociada de los conflictos procuraría que no se aplicara la sanción penal establecida, para dar prioridad a otra forma de resarcimiento común y voluntariamente acordada por las partes. La principal consecuencia del quebrantamiento del principio de legalidad sería la creación de amplios ámbitos de impunidad, pues mientras que la tramitación de un proceso penal se centra en la imposición de una pena legalmente prevista, la mediación busca la satisfacción de la víctima, pero dicha satisfacción varía dependiendo de la situación psicológica de ésta, esto implicaría que a delitos idénticos se pudieran aplicar respuestas jurídicas dispares ${ }^{28}$.

27 MOLINA CABALLERO, $\mathrm{M}^{\mathrm{a}}$. J., "Algunas fronteras de la Ley Integral contra la violencia de género...”, trab. cit., p. 21 y 23.

28 FUENTES SORIANO, O., "Sobre la mediación penal y su prohibición...”, trab. cit., p. 273, RENEDO ARENAL, Ma A., “¿Mediación penal en violencia de género? No gracias", Revista Europea de Derechos Fundamentales, p. 180 y 181, primer semestre de 2014 . 
En segundo lugar, hacer uso de la mediación podría suponer la pérdida del efecto simbólico o de prevención general característico del Derecho penal. El hecho de no aplicar el sistema judicial penal podría enviar un erróneo mensaje de laxitud a la ciudadanía que trivializaría a la agresión y convertiría, de nuevo, la violencia de género en un asunto privado, lo que supondría un retroceso en las medidas legislativas que se han adoptado en los últimos años para visibilizar la violencia en el hogar (tanto doméstica como de género) y trasladarla del ámbito privado al público ${ }^{29}$.

Asimismo, se considera que la mediación puede aportar beneficios en aquellos países en los que la víctima ha sido relegada del proceso penal, pero esta no es la situación de España dónde la víctima puede ser parte del proceso, ejercer la acción penal y la civil, renunciar a ellas o reservar la acción civil para un proceso ulterior. La introducción del nuevo mecanismo resarcitorio no otorgaría más garantías a las víctimas, sino que pondría en riesgo su ius ut procedatur, proclamado en el art. 24.1 CE. La doctrina concibe irracional establecer la mediación para reforzar la posición de la víctima y, a su vez, despojarla de su posición en el proceso penal y de los derechos y garantías que la misma detenta ${ }^{30}$.

También se aduce que plantearía problemas con respecto a la acusación popular ${ }^{31}$, ya que la presencia de ciudadanos no afectados

29 RENEDO ARENAL, M ${ }^{\mathrm{a}}$ A., “¿Mediación penal en violencia...”, trab. cit., p. 184; SALVADOR CONCEPCIÓN, R., "Beneficios y perjuicios del uso...” trab. cit., p. 4; FUENTES SORIANO, O, "Sobre la mediación penal y su prohibición...", trab. cit., p. 255 y BORGES BLÁZQUEZ, R., "La prohibición de mediación penal en violencia...”, trab cit., p. 3. Como contrapartida al impulso por convertir la violencia contra las mujeres en una cuestión de orden público y de máxima prioridad, ORTIZ PRADILLO señala que se ha limitado la autonomía de la voluntad de las víctimas de violencia de género, a través de preceptos jurídicos cargados de paternalismo que consideran que estas mujeres no están en condiciones de decidir y, por ello, decide el Estado (ORTIZ PRADILLO, J.C., "Estereotipos legales en la...”, trab. cit., p. 3 ). RENEDO ARENAL, Ma A., “¿Mediación penal en violencia...”, trab. cit., p. 187, FUENTES SORIANO, O., "Sobre la mediación penal y su prohibición...", trab. cit., p. 265.

El art. 125 CE dispone que "los ciudadanos podrán ejercer la acción popular y participar en la Administración de Justicia mediante la institución del Jurado, en la forma y con respecto aquellos procesos penales que la Ley determine, así como en los Tribunales consuetudinarios y tradicionales". De acuerdo con esto el art. 101 LECrim. proclama que la acción penal es pública y que "todos 
por el hecho delictivo sería inconciliable con la proximidad que exige la mediación entre las partes privadas, salvo que se prescindiera de la dimensión pública del delito. Implantar mecanismos de justicia restaurativa en el sistema penal español supondría suprimir el ejercicio de la acción popular, lo que implicaría una modificación de la Constitución pues se configura como un derecho constitucional, art. $125 \mathrm{CE}^{32}$.

Por otro lado, la mediación podría poner en riesgo la integridad de la víctima, existiría la posibilidad de que el agresor aprovechara el encuentro para insistir en su comportamiento ofensivo, y concretamente, en casos de violencia de género es probable que utilizara la mediación para mantener el control sobre la víctima. Pero si se diera la necesidad de adoptar medidas de protección durante el procedimiento de mediación se pondría de relieve la desigualdad entre las partes y la ausencia de arrepentimiento por parte del agresor, lo que obligaría a abandonar el procedimiento de mediación ${ }^{33}$.

La objeción más compartida con respecto al establecimiento de la mediación en el ámbito de la violencia de género es la desigualdad que existe entre las partes y, por tanto, la ausencia de equidad. La LM instaura como uno de los principios informadores del procedimiento de mediación en asuntos de Derecho civil y mercantil "la igualdad entre partes" (art. 7). Sin embargo, la LOVG hace referencia a la falta de igualdad entre mujeres y hombres en numerosas ocasiones, tanto en su Exposición de Motivos como en el art.1 LOVG ${ }^{34}$. La ausencia de igualdad es el fundamento esencial

los españoles podrán ejercerla con arreglo a las prescripciones de la Ley”; y el art. 270 LECrim. dispone que "todos los ciudadanos españoles hayan sido o no ofendidos por el delito, pueden querellarse, ejercitando la acción popular establecida en el art. 101 de esta Ley".

En este sentido, cabe destacar que el art. $57.2 \mathrm{CP}$, obliga a los órganos judiciales a imponer en casos de violencia de género, en todo caso, la prohibición de aproximación a la víctima prevista en el art. 48. 2 CP. RENEDO ARENAL considera que la instauración de la mediación en el proceso penal haría necesaria la modificación del art. 57. 2 CP (RENEDO ARENAL, $\mathrm{M}^{\circ}$ A,. "¿Mediación penal en violencia...”, trab. cit., p. 189).

${ }^{34}$ La Exposición de Motivos de la LOVG define la violencia de género como una manifestación de las relaciones de poder históricamente desiguales entre hombres y mujeres, "se trata de una violencia que se dirige contra las mujeres por el hecho mismo de serlo, por ser consideradas, por sus agresores, carentes de los derechos mínimos de libertad, respecto y capacidad de decisión”, asimismo, 
de la prohibición de la mediación en el ámbito de la violencia de género, el poder y la dominación del agresor prevalecería en la mediación, siendo los eventuales acuerdos que se lograran consecuencia de la voluntad unilateral del presunto agresor que tendría sometida a la víctima, y no del equilibrio y la equidad de las partes ${ }^{35}$.

Por otra parte, podrían conculcarse los derechos y las garantías del imputado, pues se verían comprometidos, entre otros, el derecho al debido proceso, el derecho a defensa y la presunción de inocencia. Si se incorpora la mediación en el ámbito penal se corre el peligro de que se la equipare con la autoinculpación, lo que pondría al legislador en la difícil tesitura de supeditar la prosperidad del proceso penal al resultado de la mediación o de permitir que el acusado interviniera en el procedimiento de mediación donde tiene que asumir su autoría con la recompensa de que se archivará la causa penal ${ }^{36}$.

Por último, tampoco se pueden perder de vista los costes económicos de establecer un procedimiento de mediación, pues su instauración implicaría disponer de medios personales y materiales para hacer frente a la infraestructura administrativa que requeriría un servicio institucionalizado de mediación. Además cuando ésta fuera propuesta por el Fiscal o el órgano instructor debería ser gratuita, de acuerdo con el principio de igualdad del art. $14 \mathrm{CE}^{37}$.

\subsection{Argumentos a favor}

La primera ventaja de la mediación que se suele invocar y también la más evidente es que se desarrolla en un entorno humano, flexible y

el art. 1 LOVG proclama que la dicha Ley tiene por objeto luchar contra la violencia de género como "manifestación de la discriminación, la situación de desigualdad y las relaciones de poder de los hombres sobre las mujeres".

35 RENEDO ARENAL, M ${ }^{\mathrm{a}}$ A., “¿Mediación penal en violencia...”, trab. cit., p. 191 y 192; DEL POZO PÉREZ, M., “Matices y acotaciones sobre...”, trab. cit., p. 7; FUENTES SORIANO, O., "Sobre la mediación penal y su prohibición...”, trab. cit., p. 273.

36 RENEDO ARENAL, Ma A., “¿Mediación penal en violencia...”, trab. cit., p. 193 y 194. SALVADOR CONCEPCIÓN, R., "Beneficios y perjuicios del uso...", trab cit, p. 4.

37 RENEDO ARENAL, Ma A., “¿Mediación penal en violencia...”, trab. cit., p. 195-197. 
comunicativo, ajeno a la rigidez formal del procedimiento judicial, siendo menos intimidante para la víctima. Este mecanismo se caracteriza por ser un procedimiento más abierto en el que la prioridad son las necesidades humanas reales y dónde las partes son las únicas protagonistas ${ }^{38}$.

Se entiende que con la mediación sería posible paliar las insuficiencias del sistema tradicional ${ }^{39}$. La víctima encontraría un espacio en el procedimiento, con la consiguiente reparación del daño, aunque se realizara con una obligación de hacer, recuperando su seguridad, sin que tuviera lugar la victimización secundaria al formar parte la víctima de un proceso donde antes no tenía cabida. También se considera que el agresor encontraría el beneficio de decir la verdad, de pedir perdón, reconociendo el daño causado, y contribuyendo de este modo a su rehabilitación, sorteando en algunos casos la aplicación de las penas de prisión, al sustituirlas por trabajos en beneficio de la comunidad. Asimismo, se considera que mediante este mecanismo se facilitaría el diálogo comunitario, lo que contribuiría a reconstruir la paz social quebrada por el delito y minimizaría sus consecuencias negativas, devolviendo el protagonismo en la sociedad civil ${ }^{40}$.

En particular en el ámbito penal se ha señalado que introducir la mediación ayudaría a trazar un Derecho penal orientado a la resocialización y a la concordia, ya que se prestaría una especial atención a las

38 SALVADOR CONCEPCIÓN, R., "Beneficios y perjuicios del uso...", trab. cit., p. 2.

39 FUSTERO BERNAD señala como inconvenientes del sistema tradicional los siguientes: 1 . No se rehabilita al delincuente, pues al negar los hechos, al mentir sobre los mismos y al no asumir la responsabilidad de lo sucedido, se parte de una situación muy compleja para conseguir la rehabilitación que es uno de los fines de la pena, junto con el castigo. 2. No existe una reparación para la víctima y además es víctima doblemente, por el proceso de instrucción, y se siente sola, pierde la seguridad, lo que impide que se recupere en el plano moral y en el económico, pues normalmente los delincuentes son insolventes. 3. Disgusto social, al comprobar que el procedimiento no funciona. 4. Desencanto de los jueces y profesionales del Derecho al contemplar que el procedimiento no funciona (FUSTERO BERNAD, A., "La mediación en los delitos de violencia...” trab. cit., p. 12.).

40 CASTILLEJO MANZANARES, R., TORRADO TARRÍO, C. y ALONSO SALGADO, C., "Mediación en violencia de género", Revista de Mediación, Nº7, p. 41, 2011. 
condiciones de la víctima, a los hechos y a la significación jurídico penal de la condena para el autor. Mediante la mediación se allanaría la consecución del fin de prevención especial de la pena, es decir, la reeducación y reintegración del delincuente en la sociedad, pues la función resocializadora del Derecho penal obtendría con la mediación una trascendencia especial en el proceso, ya que el agresor participaría de forma más activa en su propio proceso de resocialización debido a su reconocimiento de responsabilidad en el delito cometido ${ }^{41}$. Asimismo, se ha subrayado que la mediación contribuiría a la descongestión del sistema judicial, a la reducción de los costes temporales y económicos de los procesos judiciales, y a un mayor índice de satisfacción cualitativo y cuantitativo respecto al cumplimiento de las resoluciones judiciales, así como a un menor desgaste emocional ${ }^{42}$.

En concreto, en materia de violencia de género, se ha apuntado que el hecho de que el eje central de la mediación gire en torno a la reparación de la víctima proporcionándole ayuda, comprensión y asistencia, podría resultar muy positivo, pues en muchas ocasiones estas víctimas están más interesadas en conseguir apoyo, comprensión y una explicación de la violencia, que en el castigo para el infractor o una indemnización ${ }^{43}$.

En tal sentido, se ha sostenido que no en todas las situaciones en que se comete un delito de violencia de género prima la desigualdad fruto de la dominación del hombre sobre la mujer. Existen supuestos en los que el conflicto penal es ocasional y es aquí donde hacer uso de la mediación penal podría ser más beneficioso que recurrir al tradicional proceso penal, pues la mediación permitiría a la víctima recuperar su

41 SALVADOR CONCEPCIÓN, R., "Beneficios y perjuicios del uso...", trab cit, p. 4. Es necesario destacar, que en el Ordenamiento español se reconocen instituciones que responden a los principios de justicia restaurativa. Los artículos 21.4 y 21.5 del Código Penal prevén como circunstancias atenuantes la confesión del culpable y la reparación del daño ocasionado a la víctima, lo que podría traducirse como declaraciones del legislador de dirigirse hacia la mediación.

42 FUENTES SORIANO, O., "Sobre la mediación penal y su prohibición...”, trab. cit., p. 244 y 245.

43 SALVADOR CONCEPCIÓN, R., "Beneficios y perjuicios del uso...”, trab cit, p. 3 . 
posición de igualdad con respecto a su agresor, al reconocer éste el desvalor de su acción ${ }^{44}$. Además, se considera que la mediación favorecería el empoderamiento y autonomía de la mujer, dotándola de herramientas para prevenir estados futuros análogos, al tiempo que podría hacer frente a su situación actual; dejando atrás la imagen de ser dependiente e incapaz que subyace de la legislación vigente en violencia de género, para ser capaz de abordar y gestionar su propia realidad ${ }^{45}$.

De otro lado, se ha indicado que, en los delitos de violencia de género, a diferencia de lo que ocurre en otros tipos delictivos, la víctima es muy probable que se reencuentre con el agresor, que se reconcilie con él, o que tenga la necesidad de hablar con él sobre aspectos comunes que les unen como los hijos, bienes, deudas, etc. La justicia penal sólo puede proteger a la víctima, castigar al victimario, y en su caso, rehabilitarlo, pero no ofrece una solución real al conflicto. Sin embargo, la mediación se presenta como una posibilidad muy conveniente, puesto que la palabra se convierte en la única herramienta legítima para gestionar una controversia que, inevitablemente, los individuos han de enfrentar a lo largo de sus vidas, interiorizando el diálogo como método de solución de conflictos ${ }^{46}$.

En tal sentido, se ha señalado que la práctica evidencia un alto grado de reincidencia en los delitos de violencia de género debido al elemento diferenciador que les caracteriza, la relación de afectividad, y ante el que el proceso penal se ve incapaz de ofrecer una solución real.

${ }^{44}$ BORGES BLÁZQUEZ, R., "La prohibición de mediación penal en violencia...", trab cit., p. 3.

45 CASTILLEJO MANZANARES, R., TORRADO TARRÍO, C. y ALONSO SALGADO, C., "Mediación en violencia...", trab. cit., p. 43 y SÁNCHEZ RUÍZ, I.C. y GARCÍA-LONGORIA SERRANO, ${ }^{\mathrm{a}} \mathrm{P}$. "Un sistema alternativo para la gestión de conflictos en casos...”, trab. cit., p. 80, ORTIZ PRADILLO, J.C., "Estereotipos legales en la...", trab. cit., p. 10.

46 BORGES BLÁZQUEZ, R., "La prohibición de mediación penal en violencia...", trab cit., p. 4, CASTILLEJO MANZANARES, R., TORRADO TARRÍO, C. y ALONSO SALGADO, C., "Mediación en violencia...", trab. cit., p. 43. En este sentido, GIL VALLEJO apunta que debería considerarse la posibilidad de admitir la mediación desde la perspectiva del interés del de menor, puesto que en determinados casos debería de primar el derecho del menor a relacionarse con su progenitor así como el derecho a la solución pacífica del conflicto, ya que es la única forma de ponderar a los menores en el conflicto parental (GIL VALLEJO, B., “A vueltas con el artículo 416 LECrim....”, trab. cit., p. 10). 
Asimismo, se ha apuntado que en los casos de violencia de género en que la víctima se retracta o pide que se anulen los cargos contra el agresor, a veces sobre la base de un acuerdo para volver juntos o continuar la vida en común, es mejor la intervención de un mediador que contribuya a lograr una solución extrajudicial que consista en un acuerdo equitativo que el mero perdón otorgado por la mujer agredida a su pareja, ya que éste puede producir determinados efectos procesales al incidir en la pretensión de la víctima de retirar la denuncia, en su decisión de retroceder de los hechos inicialmente narrados o, incluso en la de no comparecer en el juicio oral ${ }^{47}$.

Por último, se ha puesto de manifiesto que, tras la promulgación de la LOVG, no se ha experimentado una disminución de los casos de violencia de género, más bien al contrario, se ha incrementado el número, los resultados son tan desoladores que se ha llegado a poner en duda la utilidad y eficacia de la Ley. El exceso punitivo con el que el legislador español ha aspirado a frenar en algunos casos el aumento de este tipo de violencia se ha convertido en un progresivo endurecimiento de penas propio de un sistema retributivo, que no ha servido para detener la violencia contra las mujeres. Pero en el ámbito internacional se han llevado acabo procedimientos de mediación en delitos graves y de violencia de género que arrojan resultados muy positivos, como casos ejemplificativos se pueden destacar EEUU, Canadá, Austria, Finlandia, Alemania o Italia. Es más, incluso, en España hay Comunidades Autónomas como Madrid, Cataluña o el País Vasco que han desarrollado proyectos piloto "alegales" en materia de violencia de género con resultados muy alentadores ${ }^{48}$.

47 ARANGÜENA FANEGO, C., "Sistemas alternativos de resolución de conflictos...", trab. cit., p. 130.

48 Véase SERRAMIÀ BALAGUER, L., "Nuevas oportunidades para la justicia restaurativa en el sistema...", trab. cit., p. 12 a 16 y, CANO SOLE, Ma . A., "La mediación penal como método de resolución de conflictos...”, trab. cit. p. 4 y 5, SÁNCHEZ RUÍZ, I. C. y GARCÍA-LONGORIA SERRANO, Ma P. "Un sistema alternativo para la gestión de conflictos en casos...”, trab. cit., p. 70 y 71 y GUARDIOLA LAGO, Ma ${ }^{\mathrm{a}}$. J., "La víctima de violencia de género en el sistema de justicia...”, trab. cit., p. 20-23. GUARDIOLA LAGO pone de manifiesto que la normativa internacional no limita la práctica de la mediación a determinados delitos ni a la fase del procedimiento penal en que se encuentren, que a lo sumo señala la necesidad de contemplar determinadas especificidades 


\section{Propuestas lege ferenda para una futura reforma}

La doctrina ha elaborado numerosas propuestas lege ferenda para implantar la mediación en el ámbito penal, y en concreto, en el de la violencia de género. Todo ello, a pesar de que la mediación en estos supuestos no solo se encuentra vedada por la prohibición del art. 87 ter 5 LOPJ, sino también por la imposibilidad de su realización debido a la redacción actual del artículo 57.2 del Código Penal que impone la obligación de aplicar la pena accesoria de prohibición de aproximación o de acercamiento sobre la víctima en los delitos de violencia de género. En este sentido, se ha aducido que la implantación de la mediación en estos supuestos requeriría una modificación del texto del art. 57.2 del Código Penal, además de la derogación del art. 87 ter. LOPJ ${ }^{49}$.

La mayoría de la doctrina entiende que la mediación penal no debería instaurarse como una alternativa al proceso, puesto que el Derecho penal no puede quedar ajeno al conflicto y dejar su resolución a la libre disposición de las partes. En concreto, se ha señalado que la mediación en violencia de género debería de definirse por el legislador como la vía alternativa desarrollada dentro del proceso penal y dirigida a aplicar el Derecho penal a través de la intervención activa de la víctima y el infractor en las fases procesales que establezca el legislador ${ }^{50}$.

metodológicas, como el establecimiento de una "co-mediación” en los supuestos de violencia de género (p.21).

49 RODRÍGUEZ YAGÜE señala que resulta contradictorio que el legislador adopte medidas tuitivas que podrían ser calificadas de "hiperprotectoras" en la medida de que se decidan en contra de la voluntad de la mujer, partiendo de su falta de capacidad de decisión y autodeterminación en el proceso una vez que éste se inicia (imposición obligatoria de la medida de alejamiento, prohibición de mediación, etc.); y que al mismo tiempo, el EVD les otorgue a las víctimas un rol y una posición en el proceso penal que permite que participen hasta en la ejecución del mismo. (RODRÍGUEZ YAGÜE, C. "Prohibición de la mediación...", trab. cit, p. 6).

50 MARTÍNEZ GARCÍA, E., "Mediación penal en los procesos por violencia de género...”, trab. cit., p. 23. En tal sentido, ARANGÜENA FANEGO ha puesto de manifiesto que la viabilidad de la mediación penal pre procesal es más que dudosa, y absolutamente rechazable en los supuestos de violencia de género (ARANGÜENA FANEGO, C., "Sistemas alternativos de resolución de conflictos...”, trab. cit., p. 151.) 
En tal sentido, se ha considerado que la fase más apropiada para articular la mediación en los supuestos de violencia de género sería la de ejecución de la condena, pues en la misma ya se habría hecho valer el ius poniendi del Estado y existiría una condena que imponer ${ }^{51}$. Asimismo, se ha esgrimido que serían los propios Jueces y Tribunales los que tomarían la decisión de derivar un determinado caso a mediación, dotando de fuerza y rigor la intervención de la autoridad judicial ${ }^{52}$. Y además, se ha apuntado que el comienzo de un proceso de mediación, una vez recaída la sentencia condenatoria al agresor, en delitos especialmente graves y violentos, puede ser positivo, pues el paso del tiempo muchas veces es trascendental para la recuperación de la víctima ${ }^{53}$. Por último, se ha señalado que la mediación serviría como una forma de canalizar una pena escuchando a la víctima y al condenado al que se le abriría la alternativa entre cumplir de forma efectiva los pactos derivados de la mediación o cumplir en sus propios términos la sentencia ${ }^{54}$.

Sin embargo, también se ha aducido que en los supuestos en que exista una posición igualitaria entre la víctima y el agresor desde el principio del proceso penal, nada debería de impedir que pudiera realizarse un procedimiento de mediación en la fase de instrucción, pues discernir los casos en que no se puede llevar a cabo una mediación por falta de igualdad entre las partes y los supuestos en los que el procedimiento restaurativo si es posible, es una cuestión compleja, que requiere de un proceso metodológico que no tiene por qué rechazar

51 MARTÍNEZ GARCÍA, E., "Mediación penal en los procesos por violencia de género...”, trab. cit., p. 27.

52 SALVADOR CONCEPCIÓN, R., "Beneficios y perjuicios del uso...", trab cit, p. 4.

53 SERRAMIÀ BALAGUER estima que, si ha existido una situación prolongada de maltrato tanto psicológico como físico, la víctima puede precisar una fase inicial de separación del agresor, y posteriormente, para abandonar la posición de víctima y recuperarse totalmente a través del empoderamiento, un contacto (directo o indirecto) con el agresor. En este sentido, la mediación puede resultar apropiada en la extinción de la pena para preparar situaciones futuras, en particular, si existen hijos en común (SERRAMIÀ BALAGUER, L., "Nuevas oportunidades para la justicia restaurativa en el sistema...”, trab.cit., p. 20).

54 ARANGÜENA FANEGO, C., "Sistemas alternativos de resolución de conflictos...", trab. cit., p. 154. 
siempre y en todo caso una respuesta restaurativa ante un supuesto de violencia de género ${ }^{55}$.

Respecto a los tipos delictivos que podrían someterse a mediación, hay autores que consideran que todos los delitos son mediables sin ninguna excepción, pues todas las personas deben tener el derecho y la libertad de decidir si admiten el perdón del delito cometido hacia su persona y si es suficiente con aceptar el arrepentimiento y el reconocimiento por parte del delincuente, de forma que para la víctima quede zanjado el hecho delictivo a nivel personal ${ }^{56}$. Otros, sin embargo, entienden que es necesario limitar la mediación a determinados tipos penales y que la misma no puede tener cabida, en ningún caso, en los delitos de violencia de género debido a la falta de equilibrio entre las partes ${ }^{57}$. También se ha aducido que lo mejor es emplear un criterio subjetivo que tenga en cuenta las características concretas de cada proceso y, que en el ámbito de la violencia de género deberían someterse a mediación solo supuestos de escasa relevancia consistentes en violencia verbal, pero nunca supuestos de violencia física o hechos constitutivos de amenazas, coacciones o vejaciones ${ }^{58}$.

No obstante, también se ha señalado que la conveniencia de llevar a cabo procesos restaurativos en supuestos de violencia de género

55 GUARDIOLA LAGO, Ma . J., "La víctima de violencia de género en el sistema de justicia...", trab. cit, p. 36.

56 FUSTERO BERNAD, A., "La mediación en los delitos de violencia..." trab. cit., p. 9.

57 FUENTES SORIANO, O., "Sobre la mediación penal y su prohibición...”, trab. cit., p. 266 y 267. FUENTES SORIANO estima que la selección de tipos penales susceptibles de ser sometidos a mediación debería realizarse atendiendo a dos criterios: uno cuantitativo, en función de la gravedad de la pena, y otro, de carácter cualitativo en el que se determinaran los tipos delictivos y los concretos bienes jurídicos protegidos afectados; o, también se podría emplear un sistema mixto con ambos criterios. No obstante, señala que el segundo criterio es más aconsejable, pues la clave de la mediación debería estar en el mayor o menor interés público que presenta la persecución de determinados delitos, al margen de la pena.

58 SALVADOR CONCEPCIÓN, R., "Beneficios y perjuicios del uso...", trab cit, p. 1, ORTIZ PRADILLO, J.C., “Estereotipos legales en la...”, trab. cit., p. 9. En tal sentido, GIL VALLEJO señala que se deben dar respuestas distintas a casos heterogéneos, distinguiendo los casos de violencia de género sistemática de aquellos otros en que la violencia de género está constituida por un hecho aislado (GIL VALLEJO, B., “A vueltas con el artículo 416 LECrim..”, trab. cit, p. 10). 
no debería de limitarse en función de la gravedad del hecho delictivo, pues la diversidad de relaciones violentas supone que no se puedan fijar reglas generales sobre la intervención de la mediación en cada caso. Si es recomendable o no el empleo de la mediación debería depender del análisis de cada caso concreto; y, sobre todo, de la concurrencia de determinados presupuestos ${ }^{59}$.

En este sentido, se entiende, que la admisión de la mediación en supuestos de violencia de género obligaría, en todo caso, a adoptar las siguientes cautelas: el equilibrio de la posición de la mujer respecto a la de su expareja y del agresor frente a la víctima, respetando sus garantías procesales durante todo el procedimiento de mediación y no privilegiando en exceso a la víctima. El consentimiento libre e informado de la víctima y del victimario, la salvaguarda de la seguridad de la víctima a través de medidas aplicadas antes, durante y después de los encuentros; la asunción de responsabilidad por el agresor, así como el reconocimiento de la naturaleza delictiva de los hechos de la víctima y del victimario; y, por último, la imparcialidad del mediador ${ }^{60}$.

En consonancia con lo anterior, las restricciones en el procedimiento de mediación no deberían efectuarse en base a las tipologías delictivas, sino más bien evaluando si se cumplen las condiciones y presupuestos necesarios para poder realizarla. En la determinación de estos supuestos sería de utilidad el marco establecido en el propio EVD que, además de partir del presupuesto del consentimiento libre e informado de la víctima y previo reconocimiento de los hechos esenciales por el

59 CASTILLEJO MANZANARES, R., "Hipótesis de partida acerca de la posibilidad...”, trab. cit., p. 8, SERRAMIÀ BALAGUER, L., "Nuevas oportunidades para la justicia restaurativa en el sistema...", trab.cit., p. 21 y 22.

ARANGÜENA FANEGO pone de manifiesto que en el Derecho internacional existen sistemas penales como el de EEUU, Alemania o los países escandinavos que permiten la mediación en delitos especialmente violentos y graves, $\mathrm{y}$ en los que lejos de considerarse desaconsejable se entiende como "altamente conveniente" (ARANGÜENA FANEGO, C., "Sistemas alternativos de resolución de conflictos...”, trab. cit., p. 115)

60 FUENTES SORIANO, O., "Sobre la mediación penal y su prohibición...”, cit., p. 277 y SALVADOR CONCEPCIÓN, R., "Beneficios y perjuicios del uso...”, trab cit, p. 12. MARTÍNEZ GARCÍA, E., "Mediación penal en los procesos por violencia de género...”, trab. cit., p. 23. 
autor, excluye la actuación de los servicios de justicia restaurativa en el caso de que se detecte algún riesgo para la seguridad de la víctima o que pueda ser causa de cualquier otro perjuicio ${ }^{61}$.

Se ha considerado que para que la mujer fuera introducida en el procedimiento mediador voluntariamente y, en todo caso, en una posición de igualdad respecto al hombre, sería necesario que su inclusión fuera precedida de una completa valoración psicológica, en la que, teniendo en cuenta la disposición de la víctima y su relación con el victimario, se valorara si es pertinente o no la mediación para cada caso específico. Pues no en todas las relaciones definidas por la violencia de género el desequilibrio entre las partes se presenta como insuperable, dentro de este tipo delictivo se pueden distinguir una inmensa diversidad de situaciones que abarcan desde una agresión ocasional, hasta el uso sistemático de la violencia como instrumento de dominación y poder ${ }^{62}$.

Es por ello que de la valoración previa de la mujer y de sus concretas circunstancias podrían inferirse distintas líneas de actuación ${ }^{63}$. Si existiese igualdad de poder, podría estimarse la conveniencia de someter el caso a mediación. En otros supuestos podría ser necesaria la intervención

61 RODRÍGUEZ YAGÜE, C., "Prohibición de la mediación...”, trab. cit, p. 5 y 6. El art. 15 EVD establece como requisitos para acceder a los servicios de justicia restaurativa los siguientes: “a) que el infractor haya reconocido los hechos esenciales de los que se deriva su responsabilidad, b) que la víctima haya prestado su consentimiento, después de haber recibido información exhaustiva e imparcial sobre su contenido, sus posibles resultados y los procedimientos existentes para hacer efectivo su cumplimiento; c) que el infractor haya prestado su consentimiento; d) que el procedimiento de mediación no entrañe un riego para la seguridad de la víctima, ni exista peligro de que su desarrollo pueda causar nuevos perjuicios materiales o morales para la víctima; y e) que no esté prohibida para el delito cometido".

62 CASTILLEJO MANZANARES, R., TORRADO TARRÍO, C. y ALONSO SALGADO, C., "Mediación en violencia...", trab. cit., p. 42

63 La doctrina considera que entre las circunstancias que deberían tomarse en cuenta en cada caso específico se encuentran las siguientes: el grado, tipo y la reiteración/periodicidad de la violencia, los daños producidos, las secuelas y la capacidad de recuperación de las mismas, la gravedad del episodio de violencia, la existencia o no de otros perjudicados (como hijos o ascendientes), el restablecimiento del equilibrio y la igualdad y el deseo de la víctima de someterse al proceso mediador (SERRAMIÀ BALAGUER, L., "Nuevas oportunidades para la justicia restaurativa en el sistema...”, trab.cit., p. 21) 
especializada de la mujer por profesionales de la mediación para que la situaran en un plano de igualdad con respecto al hombre ${ }^{64}$. Por último, también podría darse el supuesto de que debido a las circunstancias inherentes de la víctima no fuera recomendable acceder a la mediación ${ }^{65}$.

También se ha señalado que la falta de equilibrio debería de analizarse en cada fase del proceso, pues podría ocurrir que, de existir tal desequilibrio, transcurrido un tiempo se supere, y sea la propia víctima la que requiera, o incluso, necesite, dejar su posición de víctima a través de un procedimiento de mediación ${ }^{66}$. Pero en todo caso, la mediación habría de regirse por los principios de igualdad y voluntariedad, asegurando la libertad de decisión de la mujer y del victimario tanto en el momento de inicio como en el desarrollo del procedimiento. Para garantizar la seguridad de la víctima se ha abogado por la llamada "mediación indirecta o subrogada", en la que la mediación no se efectúa directamente careando a ambas partes sino mediante un tercero o a través de sesiones individuales y no conjuntas, impidiendo así la manipulación que el maltratador pudiera ejercer sobre la víctima ${ }^{67}$.

En cuanto a los mediadores, se ha manifestado que solo podrían desempeñar este cargo los equipos psicosociales o las Unidades de Valoración Integral, pero nunca el órgano jurisdiccional ni la Fiscalía o la policía. Para obtener la capacitación necesaria para ser mediador, además de la preparación que exija la Ley de mediación penal, en los supuestos de violencia contra las mujeres sería precisa una especialización en materia de género e

64 CANO SOLE considera que una vez que la víctima adquiere de nuevo su control y se recupera de las secuelas del maltrato no puede resultarle conveniente enfrentarse de nuevo al maltratador, porque de ser así se caería en la incoherencia de "recuperar" a la víctima para que ésta entre de nuevo "en los dominios del maltratador" (CANO SOLE, Ma A., "La mediación penal como método de resolución de conflictos...”, trab. cit., p. 11).

CASTILLEJO MANZANARES, R., TORRADO TARRÍO, C. y ALONSO SALGADO, C., "Mediación en violencia...", trab. cit., p. 42. Las autoras entienden que la aceptación de la víctima de someterse a un proceso de empoderamiento, con carácter previo a la mediación, debería ser preceptiva. De forma que, se limitara la participación de la víctima en el procedimiento de mediación no solo a que prestara su consentimiento personal, sino también a que el informe del profesional de la psicología que evaluara su estado fuera positivo. RODRÍGUEZ YAGÜE, C., "Prohibición de la mediación...”, trab. cit, p. 5 MOLINA CABALLERO, Ma J., "Algunas fronteras de la Ley Integral contra la violencia de género...”, trab. cit., p. 19. 
igualdad $^{68}$. Por último, se ha señalado que debería regularse expresamente la confidencialidad de la información obtenida durante la mediación y el secreto profesional del mediador respecto de los hechos y las circunstancias que le han sido confiados, así como que no pueda ser llamado como testigo ni perito. Y a las partes se les debe de prohibir utilizar como prueba en un proceso penal posterior los hechos reconocidos en el contexto de la mediación a los efectos de salvaguardar la presunción de inocencia del agresor ${ }^{69}$.

\section{VALORACIÓN FINAL}

Tras el análisis de la legislación vigente, de los argumentos a favor y en contra de la doctrina, y de las propuestas lege ferenda que se han aportado para poder aplicar la mediación en casos de violencia de género, considero que la prohibición de la mediación prevista en el artículo 87.ter LOPJ para este tipo de delitos no se debe seguir manteniendo. Si bien la LOVG ha supuesto un hito relevante en España porque ha permitido trasladar del ámbito privado al ámbito público la violencia que durante muchos siglos han sufrido las mujeres en sus casas, también lo es que la mentada ley presenta algunas carencias que deben ser subsanadas sin demora por el legislador.

Una de esas deficiencias es precisamente el establecimiento de la prohibición de practicar procedimientos de mediación en todos los supuestos de violencia de género (art. 44.5 LOVG), tal prohibición se fundamenta en una concepción vulnerable y débil de la mujer, que superada por la situación de violencia se ve incapaz de llevar las riendas de su vida y de tomar sus propias decisiones, pero esta concepción de la mujer víctima de violencia no siempre coincide con la realidad y en muchas ocasiones está lejos de la misma. En violencia de género no todas

68 MARTÍNEZ GARCÍA, E., "Mediación penal en los procesos por violencia de género...”, trab. cit., p. 31 y CASTILLEJO MANZANARES, R, TORRADO TARRÍO, C. y ALONSO SALGADO, C., "Mediación en violencia...”, trab. cit., p. 44. Actualmente, la formación de los mediadores en asuntos civiles y mercantiles se encuentra regulada en el Título III, arts. 11 a 15 de la LM y en Real Decreto 980/2013, de 13 de diciembre, por el que se desarrollan determinados aspectos de la LM, arts. 3 a 7.

69 ARANGÜENA FANEGO, C., "Sistemas alternativos de resolución de conflictos...”, trab. cit., p. 137, 138 y 159. 
las víctimas son iguales, algunas se encuentran en una situación de gran vulnerabilidad, otras son conscientes del carácter reprochable de los hechos y deciden terminar con la relación de violencia sin encontrarse en una situación de desigualdad frente al hombre, también las hay que necesitan un tiempo para recuperarse y empoderarse, etc. No existe un estereotipo general de víctima de violencia de género, por tanto, el legislador español está impidiendo con su prohibición absoluta que las mujeres que no se encuentran en una situación de vulnerabilidad y de desequilibrio y prefieran someter su caso a mediación no puedan hacerlo, coartando así su libertad y la autonomía de su voluntad.

En tal sentido, tanto el estereotipo de víctima que estableció el legislador como su decisión de prohibir la mediación en todos los supuestos de violencia de género fueron demasiado prematuros, y más a la vista de la experiencia internacional, la cual es muy alentadora con respecto al uso de la mediación en casos de violencia de género, incluso cuando sean especialmente graves. Es por ello que la inminente regulación de la justicia restaurativa en el orden penal, en consonancia con el mandato europeo, debe llevar aparejada la derogación del art. 87 ter 5 LOPJ y de todos los obstáculos legales que impiden la aplicación de estos procedimientos en los casos de violencia de género.

La mediación en el ámbito penal, y en concreto, en los supuestos de violencia de género no debe instaurase como una alternativa al proceso penal, sino que debe integrarse en éste para desarrollarse en alguna de sus fases procesales, y sus objetivos primordiales deben ser la recuperación de la víctima y la resocialización del delincuente. En cuanto a la fase del proceso más conveniente para celebrar la mediación, debería de depender de la víctima y de las circunstancias específicas del caso concreto, pues puede haber procesos en los que ya desde el inicio la víctima esté preparada para someterse a este tipo de mecanismos y quiera hacerlo. No obstante, en supuestos de violencia de género especialmente graves, la fase más indicada para una posible mediación sería la de ejecución de la sentencia, aunque habría que evaluar el caso concreto.

Por lo mismo que se ha expuesto anteriormente, no se debe establecer un numerus clausus de delitos susceptibles de mediación, la decisión de derivar un determinado delito a mediación debe hacerse tras una evaluación pormenorizada del caso. Sería indispensable que previamente un profesional de la mediación tuviera una entrevista individual y separada 
con la víctima y con el agresor, para cerciorarse que ambos se someten voluntariamente al procedimiento, que son conscientes del carácter delictivo de los hechos, que conocen las consecuencias que conlleva someterse al mismo y, sobre todo, en supuestos de violencia de género que efectivamente existe equilibrio e igualdad entre la víctima y el agresor.

Sería conveniente que, la víctima de violencia de género, antes de que se efectuara la entrevista individual con el mediador fuera evaluada por un experto o psicólogo que valorara si verdaderamente se encuentra en condiciones se iniciar un procedimiento de mediación. La mediación indirecta podría ser una buena alternativa no solo para salvaguardar la seguridad de la víctima, sino también para aquellos casos en que las víctimas quieran someterse a un procedimiento de mediación, pero prefieran no tener un contacto directo con el agresor, o al menos en un principio. La figura del mediador es esencial para que se cumplan todos los principios que deben inspirar un procedimiento mediador, en este sentido, es necesario que su formación y especialización sean las adecuadas. Por último, es preciso que la confidencialidad de la información y el secreto profesional se regulen con detalle en la futura ley de mediación penal, en aras a salvaguardar la presunción de inocencia del agresor.

No obstante, pese a lo expuesto, no parece que las intenciones del legislador español se dirijan a derogar la prohibición del artículo 87 ter LOPJ, más bien van encaminadas a reforzarla si se tiene en cuenta lo prevenido en el Pacto de Estado contra la violencia de género respecto al uso de la mediación en este tipo de delitos. Solo queda esperar a la futura regulación de los procedimientos de justicia restaurativa en el ámbito penal, la cual no debería retrasarse mucho más, y ver si tanto la experiencia internacional como las críticas y propuestas de la doctrina hacen que el legislador derogue definitivamente la prohibición de la mediación en materia de violencia de género.

\section{Bibliografía}

ÁLVAREZ SUÁREZ, L., "La posición jurídico-procesal de las víctimas de violencia de género: estudio hispano-italiano", Revista de derecho y proceso penal, $\mathrm{N}^{\circ} 51, \mathrm{p}$. 149-172, 2018.

ARANGÜENA FANEGO, C., "Sistemas alternativos de resolución de conflictos en el ámbito penal". En: ARANGÜENA FANEGO, C, HOYOS SANCHO, M. y CABRERA 
MERCADO, R., Análisis de medidas para mejorar la protección judicial y policial de las víctimas de violencia de género, Ministerio de Sanidad, Política Social e Igualdad, Madrid, p. 127-160, 2011. Texto disponible en: https://www.mimp.gob.pe/files/programas_nacionales/pncvfs/Proyecto_Apoyo_Asociacion_Juristas/Analisis_Medidas_Mejorar_Proteccion_Policial_Judicial_Victimas_Violencia_Genero.pdf (último acceso febrero 2019).

BORGES BLÁZQUEZ, R., "La prohibición de mediación penal en violencia de género ¿éxito o fracaso?, Diario La Ley, N 9100, p. 1-6, 2017.

CANO SOLE, Ma A., "La mediación penal como método de resolución de conflictos. Posibilidades de aplicación a los delitos de violencia de género y doméstica”, La Ley Penal, $\mathrm{N}^{\circ}$ 109, p. 1-18, 1014.

CASTILLEJO MANZANARES, R., TORRADO TARRÍO, C. y ALONSO SALGADO, C., "Mediación en violencia de género", Revista de Mediación, Nº7, p. 38- 45, 2011.

CASTILLEJO MANZANARES, R., "Hipótesis de partida acerca de la posibilidad de mediación en supuestos de violencia de género”, Diario La Ley, № 8882, p.1-9, 2016.

DEL POZO PÉREZ, M., "Matices y acotaciones sobre la prohibición de mediación del art. 44.5 de la Ley Orgánica 1/2004”, La Ley, Nº 98/99, p. 1-11, 2012.

GIL VALLEJO, B. “A vueltas con el artículo 416 LECrim. (Repercusión de la Sentencia del Tribunal Supremo de 14 de julio de 2015 en el uso de la dispensa del art. 416.1 LECrim., por las víctimas de la violencia de género. La mediación en el ámbito de la violencia de género. Necesidad de flexibilización del sistema actual)”, Diario La Ley, ํ 8764, p. 1-10, 2016.

GUARDIOLA LAGO, Ma . J., "La víctima de violencia de género en el sistema de justicia y la prohibición de la mediación penal”, Revista General de Derecho Penal, $\mathrm{N}^{\circ} 12$, p. 1-40., 2009.

FUENTES SORIANO, O., "Sobre la mediación penal y su prohibición en violencia de género”. En: CASTILLO FELIPE, R. y TOMÁS TOMÁS, S., Estudios sobre la mediación y arbitraje desde una perspectiva procesal, Thomson Reuters Aranzadi, p. 239-277, 2017.

FUSTERO BERNAD, A., "La mediación en los delitos de violencia de género", Revista Internacional de Mediación, $\mathrm{N}^{\circ}$ 1, p. 8-23, 2014.

LARRAURI PIOJAN, E., “Justicia restauradora y violencia doméstica”. En ASUA BATARRITA, A. y GARRO CARRERA, E., Hechos postdelictivos y sistema de individualización de la pena, p.125-144, 2009. Texto disponible en: http://www.susepe. rs.gov.br/upload/1325076458_Justicia\%20Restauradora\%20y\%20Violencia\%20 Dom\%C3\%A9stica-\%20Elena\%20Larrauri.pdf (último acceso febrero 2019).

MARTÍNEZ GARCÍA, E., "Mediación penal en los procesos por violencia de género. Entre la solución real del conflicto y el ius poniendi del Estado", Revista de Derecho Penal, N³3, p. 10-32, 2011. 
MOLINA CABALLERO, Ma J., "Algunas fronteras de la Ley Integral contra la violencia de género: Jurisdicción de menores y mediación”, Revista Criminológica de Ciencia Penal y Criminología, No 17-24, p. 1-23, 2015.

ORTIZ PRADILLO, J.C., "Estereotipos legales en la lucha contra la violencia machista: la irrelevancia de la voluntad de la víctima”, Diario La Ley, $\mathrm{N}^{\circ} 8697$, p. 1-22, 2016.

RENEDO ARENAL, Ma A., “¿Mediación penal en violencia de género? No gracias”, Revista Europea de Derechos Fundamentales, p. 177 -198, primer semestre de 2014.

RODRÍGUEZ YAGÜE, C., "Prohibición de la mediación en los delitos de violencia de género: su incidencia en la ejecución”, La Ley Penal, No 130, p. 1-8, 2018.

SALVADOR CONCEPCIÓN, R., "Beneficios y perjuicios del uso de la mediación en el ámbito penal. Especial alusión al supuesto de violencia de género", La Ley Penal, No 112, p. 1-23, 2015.

SÁNCHEZ RUÍZ, I. C. y GARCÍA-LONGORIA SERRANO, Ma P., "Un sistema alternativo para la gestión de conflictos en casos de violencia de género: La mediación”, Revista chilena de Derecho y Ciencia política, Vol. 6, № 3, p. 65-82, 2015.

SERRAMIÀ BALAGUER, L., "Nuevas oportunidades para la justicia restaurativa en el sistema penal tras las reformas legales del año 2015: Especial incidencia en la violencia de género", Dereito, Vol. 26, N², p. 1-30, 2017.

VIDALES RODRÍGUEZ, C., "La mediación penal análisis y perspectivas tras la reforma del Código Penal y la aprobación del Estatuto de la víctima del delito”, Revista Aranzadi de Derecho y Proceso Penal, N³9, Cizur Menor, p. 1-19, 2015.

\section{Informações adicionais e declarações dos autores (integridade científica)}

Declaração de conflito de interesses (conflict of interest declaration): a autora confirma que não há conflitos de interesse na realização das pesquisas expostas e na redação deste artigo.

Declaração de autoria e especificação das contribuições (declaration of authorship): todas e somente as pessoas que atendem os requisitos de autoria deste artigo estão listadas como autores; todos os coautores se responsabilizam integralmente por este trabalho em sua totalidade. 
Declaração de ineditismo e originalidade (declaration of originality): a autora assegura que o texto aqui publicado não foi divulgado anteriormente em outro meio e que futura republicação somente se realizará com a indicação expressa da referência desta publicação original; também atesta que não há plágio de terceiros ou autoplágio.

\section{Dados do processo editorial}

(http://www.ibraspp.com.br/revista/index.php/RBDPP/about/editorialPolicies)

- Recebido em: 10/12/2018

Equipe editorial envolvida

- Controle preliminar e verificação de plágio: $16 / 12 / 2018$

- Avaliação 1: 25/12/2018

- Avaliação 2: 31/12/2018

- Editor-chefe: 1 (VGV)

- Editor-associado: 1 (ELL)

- Revisores: 4

- Avaliação 3: 02/01/2019

- Avaliação 4: 08/01/2019

- Decisão editorial preliminar: 15/02/2019

- Deslocamento ao V5N2 e aviso autora: $15 / 02 / 2019$

- Retorno rodada de correções: 26/03/2019

- Decisão editorial final: 30/03/2019

\section{COMO CITAR ESTE ARTIGO:}

ÁLVAREZ SUÁREZ, Laura. La mediación penal y su prohibición en supuestos de violencia de género: modelo español. Revista Brasileira de Direito Processual Penal, Porto Alegre, vol. 5, n. 2, p. 1075-1106, mai./ago. 2019. https://doi.org/10.22197/rbdpp.v5i2.202

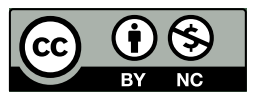

Esta obra está licenciada com uma Licença Creative Commons Atribuição-NãoComercial 4.0 Internacional. 